\title{
Small Medium Enterprises Affected by COVID-19 on the Lathon Program
}

\author{
Hilarion Hamjen ${ }^{1, *}$ Shera Mayangsari Suwito ${ }^{1}$ Annisa Muthia Yana Ariyanti ${ }^{1}$
}

${ }^{1}$ The Agency of Research and Development of Human Resources of the Ministry of Communication and Information Technology of The Republic of Indonesia, Jakarta, Indonesia Corresponding author.Email : hamjen1g@gmail.com

\begin{abstract}
Lathon is a marketplace application for street vendors and Small and Medium Enterprises (SMEs) products developed from the Hilarion program, one of the winners of the COVID-19 INA Ideathon 2020 organized by the Ministry of Research and Technology/National Agency for Research and Innovation of Indonesia. In the program, a total of 50 traders were recorded, consisting of 24\% Street Vendors and $76 \%$ SMEs affected by COVID-19 to be assisted in selling their products online. Research on these traders is considered important and urgent in the COVID-19 pandemic to find out the amount of income earned by traders during the COVID-19 pandemic, what business was most affected, and how many of the traders had already made sales online or willing to be helped by selling it online. This research was conducted using survey methods and quantitative approaches, with saturated sampling techniques on 50 respondents from the street vendors and SMEs who were recorded at the Lathon marketplace. The analysis was using Maslow's Hierarchy of Needs theory. The results show that during the COVID-19 pandemic, the average daily income decreased by $50 \%$. The most dominantly affected commodity is the culinary business, at 74\%, while the percentage who sells online is $80 \%$. Approximately $86.1 \%$ sell their products using social media, and only a small fraction $(8.3 \%)$ use traditional market for transaction. So most of the traders, 98\%, are willing to be assisted by the Lathon application. In conclusion, the most impactful commodity is the culinary business $74 \%$, a physiological need, or the most basic need in Maslow's hierarchy of needs to fulfill the right to survive. Traders who switch to online sales will be able to minimize the economic impact during the pandemic.
\end{abstract}

Keywords: COVID-19, SME's, Lathon, Marketplace, Application.

\section{INTRODUCTION}

The COVID-19 pandemic has limited conventional traders' movement, who are mostly selling activities in the outside environment because they are faced with the threat of spreading viruses that can harm their health. It is related to Law Number 39 of 1999 article 9 paragraph 3 concerning Human Rights, which states that everyone has the right to a good and healthy environment. Eventually, traders still have to run the economy's wheels or their businesses to survive. As stated in Article 9 paragraph 1, everyone has the right to live, survive, and improve their living standards. In such conditions, these rights are accommodated by transforming to digital marketing by utilizing E-commerce or marketplace application. The Lathon is a marketplace application for street vendors and Small and Medium Enterprises (SMEs) products developed from the Hilarion program, one of the winners of the COVID-19 INA Ideathon 2020 organized by the Ministry of Research and Technology/National Agency for Research and Innovation of Indonesia. In the program, 50 traders were recorded, consisting of $24 \%$ Street Vendors and $76 \%$ SMEs affected by COVID-19 to be assisted in selling their products online. Research on these traders is 
considered important and urgent in the COVID-19 pandemic because it is strongly related to the traders' survival. The research is carried out to find out how much the income the traders earn during the COVID-19 pandemic, what business was most affected, and how many of the traders had already made sales online or willing to be helped by selling it online. It is expectated that traders would switch to online sales to minimize the economic impact during the pandemic.

According to Kamus Besar Bahasa Indonesia, the impact is a very strong that it brings both negative and positive consequences. Meanwhile, according to Soemarwoto (2009), the impact is a change that occurs as an activity, and that activity can be carried out by humans, which leads to changes in human life itself [1]

According to Law No. 20 of 2008, small businesses are independent productive economic enterprises, carried out by individuals or business entities that are not subsidiaries or branches of medium or large business companies. Small businesses have 50 million to 500 million asset criteria and the criteria for a turnover of 300 million to 2.5 billion rupiah. Meanwhile, for the medium enterprises, their assets' criteria must be 500 million to 10 billion per year and a turnover of 2.5 billion to 50 billion rupiahs. SME's social goal is to achieve a minimum level of welfare that is ensuring the basic needs of the people. [1]

According to Law No. 20 of 2008, Small and Medium Enterprises (UKM) is a small business net worth of at most Rp. 200,000,000 excluding land and buildings for business premises and a standalone business. Indonesia is dominated by Micro, Small and Medium Enterprises (SMEs) [2]

Small and Medium Enterprises (SME's) were proven to increase the country's economic condition due to its capability to retain the product, and capital flow stays inside. SME's tend to be more creative than large and traditional enterprises, though the profitability may vary across the segment. [3]

Amid COVID-19, direct sales generally have decreased due to the pattern of people staying more at home. Many SMEs also choose not to open shops because of the operational hours restrictions or the imposition of Large-Scale Social Restrictions (PSBB) in several areas of E-commerce sales. The COVID-19 pandemic has had a very negative impact on SMEs. At this time SMEs have difficulty in marketing their products because of the social distance policy. By far, marketing for SMEs has only been conducted conventionally means has not implemented digital marketing due to SMEs actors' the limited knowledge.[4]

Constraints to the implementation of ecommerce in Indonesia includes two things, namely technical constraints and non-technical obstacles. Technical constraints, such as the absence of ecommerce quality standards, system security, and reliability, bandwidth, web server, and network issues. Meanwhile, non-technical constraints are regulation, the perception that e-commerce is unsafe and expensive. [5] Regarding the perception of insecurity on the internet, the element of trust is an important factor in the current era of computermediated communication. In e-commerce, the element of trust becomes an aspect that underlies the ongoing transaction process and needs to be managed properly because it can affect the adoption and development of the e-commerce sector. [6] In Kearney's research, it is known that the reasons consumers feel insecure in conducting e-commerce transactions are the existence of regulatory gaps, no cross-border jurisdiction, and the existence of cybercrime, which is difficult to avoid. [7]

The electronic system on the e-commerce platform currently facilitates financial transactions with main activities such as ordering, payment, order fulfillment, and order delivery. Along with the development of technology, the e-commerce sector has also shifted. E-commerce activities that were originally website-based have shifted to mobile applications. This is due to the the increase in the number of mobile device users and also to make it easier for e-commerce users. E-commerce mobile applications make it easier for users to access e-commerce anytime and anywhere. [8]

Essentially, sales and purchase transactions in ecommerce are almost the same as those carried out traditionally. What distinguishes here is ordering and payment made online [9]

This study uses Maslow's Hierarchy of Needs Theory to analyze the findings of the problem formulation. As stated by Abraham Maslow regarding the Hierarchy of Needs Theory, a person's need or satisfaction is plural, which includes biological needs and psychological needs in the form of material and non-material [10].

According to Maslow [11], five basic needs are always experienced by an individual hierarchically 1) Physiological Needs, for example, basic/primary needs such as payment/wages/salary, food and 
oxygen. 2) The need for a sense of security (Safety Needs), for example, the need for job security/permanent work, pension money, freedom from conflict, crime, etc. 3) Needs to be accepted (Social Needs) for example, workgroups, colleagues, family, groups, communities. 4) The need to be appreciated (Self Esteem Needs), praise, high status. 5) Self-actualization needs, for example, opportunities for training, selfdevelopment, creativity, achievement, etc.

Maslow asserts that every human being is a whole personality that is integral to distinctive and organized. Basic (physical) needs, namely physiological needs, has to be fulllfiled before moving on to fulfilling psychological needs at the next stage, namely feeling safe, social, self-esteem, and self-actualization [12]

E-commerce are activities to earn income or income that can be used for fulfilling physical needs but physical needs alone is not sufficient for participants, because it requires further needs, namely the need for safety (safety needs), the sense of security referred to because they have a steady income [13]

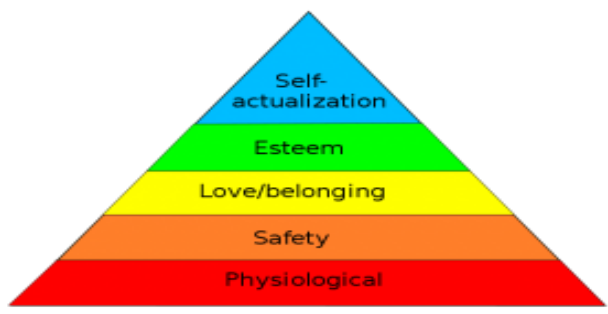

Fig. 1 Maslow's Hierarchy of Needs

Previous or relevant research related to the present study, among other studies entitled The Impact of COVID-19 on SMEs in Indonesia, was written by Andi Amri [14]. In this study, it is known that there has been a significant decline in the turnover of MSME players due to COVID-19 since the end of 2019. The tourism industry is one of the industries affected by the spread of this virus. The decline in the tourism sector has a domino effect on SMEs engaged in micro food and beverage businesses. This study uses a qualitative descriptive method. The scope of the research is national. [14] The difference with this study is that this study uses a quantitative approach with a more specific population scope for SMEs registered in the Lathon program. Also, this study examines the direct impact on the MSME sector, excluding the tourism sector.
Another study is a study entitled MSME Survival Strategies in the Middle of the COVID-19 Pandemic, written by Wan Laura Hardilawati. [15] This research uses a qualitative analysis method with exploratory steps and participatory observation techniques. The results showed that the survival strategy for SMEs in the form of trading in ecommerce was to improve product quality, add services, and optimize customer marketing relationships. [15]. This research is different from others in a way that it uses a qualitative approach and specifically utilizes an e-commerce application.

Furthermore, a study about COVID-19 and its implications for micro, small and medium enterprises written by Aknolt Kristian Pakpahan [16] reveals that the COVID-19 pandemic has economic, social, and political implications. Indonesia is one of the countries affected, especially on the economic side. Indonesia is dominated by Micro, Small, and Medium Enterprises (SMEs). It needs to pay special attention to this sector because-SMEs' contribution of SMEs to the National economy is quite large. This paper attempts to analyze the impact of the COVID-19 pandemic on the existence in Indonesia and strategies to help SMEs survive the COVID-19 pandemic. In the form of short-term policies, strategies prepared are financial assistance in the form of soft loans or cash. Meanwhile, the longterm strategy is focused on the introduction and use of digital technology for SMEs. [16] The difference is that this study uses secondary data, while the present study uses primary data with a quantitative approach and is more specific in e-commerce.

The research entitled Delivers Micro, Small, and Medium Enterprises from the Impact of the COVID-19 Pandemic, written by Dani Sugiri, suggested that the MSME sector in Indonesia experienced the impact of the COVID-19 Pandemic. These impacts successively decreased sales, causing capital difficulties, product distribution constraints, and difficult access to raw material. Several policies have been implemented by providing social assistance to poor and vulnerable MSME actors, tax incentives for SMEs, relaxation and credit restructuring for SMEs, and expansion of financing. MSME working capital and e-learning training. [2] There are differences in research approaches because it is more specific to discuss the quantity of SMEs affected by COVID19 On the Lathon program. 


\section{RESEARCH METHOD}

This research was conducted using survey methods and quantitative approaches, with saturated sampling techniques on 50 respondents from the street vendors (76\%) and SMEs (24\%) who were recorded at the Lathon marketplace. For the data collection, we still pay attention to social distancing with the traders, by collecting cellphone numbers of traders and we conduct long-distance surveys using telephone and instant messaging with small traders who are directly affected by COVID19. The analysis was using Maslow's Hierarchy of Needs theory and other secondary literature.

At the initial stage, the validity and reliability test of the research instrument in the form of a questionnaire were carried out, with items that could be tested for validity using the Pearson product-moment correlation technique. The reliability test was carried out using the Cronchbach Alfa method. There are 3 items of validity and reliability so that it can be done on 30 respondents. In the product-moment validity test, the Pearson instrument is said to be valid if the correlation value (Pearson's Correlation) is positive, and the calculated $\mathrm{R}$-value is greater than the $\mathrm{R}$ table value ( $\mathrm{R}$ count $>\mathrm{R}$ table, then the correlation probability value (sig. (2-tailed) <significance level ( 0.05), then the item is declared valid, meanwhile, for the reliability test using the Cronbach alpha method. The item is said to be reliable if the Cronbach alpha value> $\mathrm{R}$ table. The $\mathrm{R}$ table value is obtained from the product-moment $r$ table. [17]

Based on the results of the Pearson's correlation test using the SPSS application, the calculated rvalue shown in -fig. 2 follows:

\begin{tabular}{|c|c|c|c|c|c|}
\hline \multicolumn{6}{|c|}{ Correlations } \\
\hline & & question2 & question6 & Question8 & SkorTotal \\
\hline \multirow[t]{3}{*}{ question2 } & Pearson Correlation & 1 & -.238 & .244 & .686 \\
\hline & Sig. (2-tailed) & & .206 & .194 & .000 \\
\hline & $\mathrm{N}$ & 30 & 30 & 30 & 30 \\
\hline \multirow[t]{3}{*}{ question6 } & Pearson Correlation & -238 & 1 & -.058 & $.488^{\circ}$ \\
\hline & Sig. (2-tailed) & .206 & & .761 & .006 \\
\hline & $\mathrm{N}$ & 30 & 30 & 30 & 30 \\
\hline \multirow[t]{3}{*}{ Question8 } & Pearson Correlation & .244 & -058 & 1 & .441 \\
\hline & Sig. (2-tailed) & .194 & .761 & & .015 \\
\hline & $\mathrm{N}$ & 30 & 30 & 30 & 30 \\
\hline \multirow[t]{3}{*}{ SkorTotal } & Pearson Correlation & $.686^{-}$ & $.488^{-}$ & $.441^{\circ}$ & 1 \\
\hline & Sig. (2-tailed) & .000 & .006 & .015 & \\
\hline & $\mathrm{N}$ & 30 & 30 & 30 & 30 \\
\hline
\end{tabular}

Fig.2. Pearson Correlation
The calculated $\mathrm{R}$-value for each item is positive respectively $0.686,0.486$ and 0.441 and the sig (2tailed) values are $0,0.006$ and 0.015 , respectively. While the value of $r$ table can be seen from the following fig. 3 :

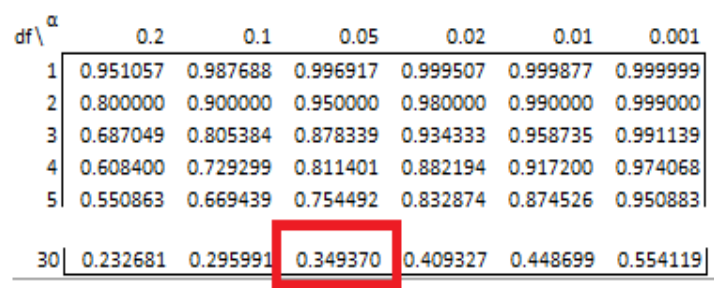

Fig.3. R Table

The number of respondents to the questionnaire test was 30 , and the significant level was 0.05 , so it is known that the $\mathrm{R}$ table's value is 0.349 . According to figure 2, the calculated R-value of each item, namely $0.686,0.486$, and 0.441 is greater than the $\mathrm{R}$ table value (0.349). The item is declared valid. The sig (2-tailed) value is $0,0.006$ and $0.015<0,05$ then the entire item is declared valid.

Furthermore, based on the Cronbach alpha reliability test, the results are obtained in the following table:

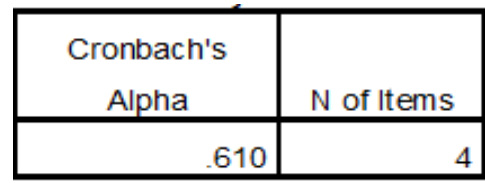

Fig. 4. Cronchbach Alfa

Because the Cronbach alpha value is greater than the $\mathrm{R}$ table value $(0.610>0.349)$ with a $5 \%$ significance, the questionnaire is reliability.

\section{FINDINGS AND DISCUSSION}

In this study, several findings were obtained, including the types of traders affected by COVID19, the types of businesses affected by COVID-19, the income of traders before and after COVID-19, the number of merchants who sell online, and the number of traders who are willing to be assisted by online sales, respectively discussed as follows. 


\subsection{Types of Traders Affected by COVID- 19}

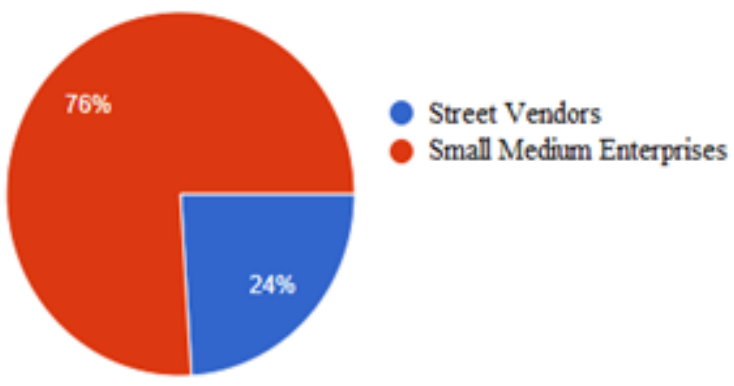

Fig.5.Traders Type

According to Law No. 20 of 2008, Small and Medium Enterprises (UKM) is a small business net worth of at most Rp. 200,000,000 excluding land and buildings for business premises and a stand-alone business [2]. In fact, according to this definition, the total income of street vendors registered in this program also has the criteria as a small business, which distinguishes it from selling locations, if the small business referred to in SMEs sells at home or shop locations while street vendors sell on the side of the road.

\subsection{Types of Businesses}

The findings related to the types of business of traders affected by COVID-19 show that the most dominant type of business is a culinary business with a percentage of $74 \%$, then handicraft business with a percentage of $6 \%$, and other businesses such as groceries, children's toys, household furniture at the percentage of $4 \%$. As shown in the following figure:

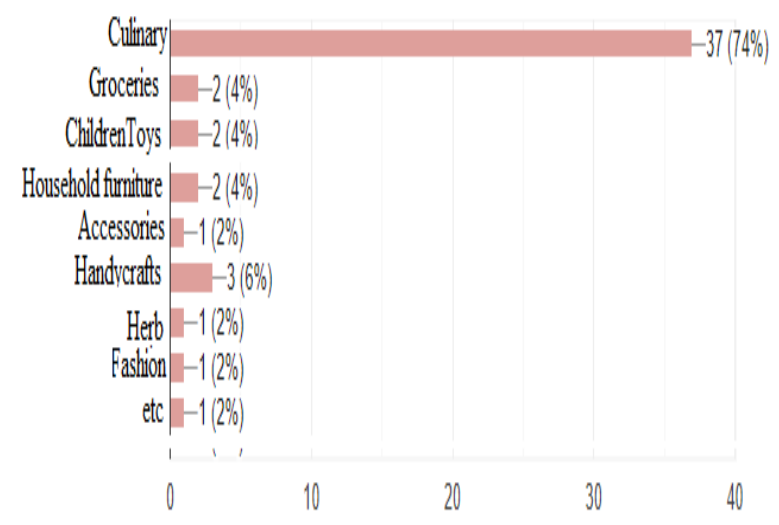

Fig.6.Type of Bussiness Affected by
According to Maslow, basic (physical) needs are physiological needs that have to be fulfilled before moving on fulfilling psychological needs at the next stage are [12]. The results showed that the type of business most affected by Covid-9 is a culinary business, which is a basic (physical) need that must be fulfilled because it is also a basic human right of faith listed in Law Number 39 of 1999 article 9 paragraph 3 concerning Human Rights, which states stated in Article 9 paragraph 1 that everyone has the right to live, to survive, and to improve their standard of living.

This impact must be dealt with as soon as possible to ensure that the culinary entrepreneurs can still provide basic needs for the community to survive in the conditions of the COVID-19 pandemic that hit the world. One of the efforts is by carrying out digital transformation and utilizing digital spaces to market products. especially culinary because it is a basic need of society and is a human right protected by laws and regulations.

\subsection{The Income of Traders Before and After being Affected by COVID-19}

According to Indonesia dictionary, the impact is a strong influence that brings both negative and positive consequences. Meanwhile, according to Soemarwoto (2009), the impact is a change that occurs as an activity, and that activity can be carried out by humans, which leads to changes in human life itself [1]. By the definition, What is meant by the impact in this research is the negative impact on the economy experienced by traders, such as a decrease in daily income figures after the COVID-19 pandemic outbreak. At the same time, the activities that have changed are the existence of social restriction activities due to COVID-19. These changes are shown in the following image: 


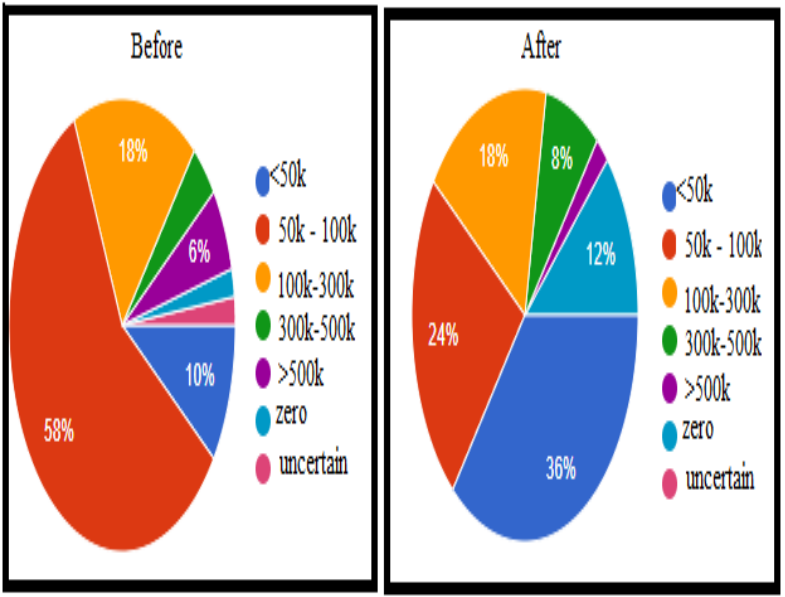

Fig.7 Income of traders before and after COVID-19

Based on this figure, it is known that daily income after the COVID-19 pandemic is reduced. Before COVID-19, 58\% of traders earned 50k-100k daily, while after COVID-19 stroke, the percentage of traders who had $50 \mathrm{k}-10 \mathrm{k}$ incomes decreased to $24 \%$. Before COVID-19, 6\% of traders earned $>500 \mathrm{k}$, but after COVID-19, the figure decreased to $2 \%$. Overal, the average daily income decreased by $50 \%$.

This reduction in merchant income is not only in the special scope of the Lathon marketplace but on a national scale. The decline in MSME players' turnover due to COVID-19 has been very significant since the end of 2019. [14] Eventhough Small and Medium Enterprises $\left(\mathrm{SME}^{\mathrm{ee}} \mathrm{s}\right)$ was proven to increase the country's economic condition due to its capability to retain the product and capital flow stay inside.[3] but the reduction in merchant income is able to decreace the country's economic condition

\subsection{The Number of Online Merchants}

Traders affected by Covid 19 have not only carried out buying and selling activities in conventional spaces, but they have also carried out buying and selling activities in the digital space or selling online. This is indicated by the research findings which reveal that most traders $(80 \%)$ are already selling online, while a small proportion $(20 \%)$ have never conducted online selling activities. As shown in the picture on the next page:

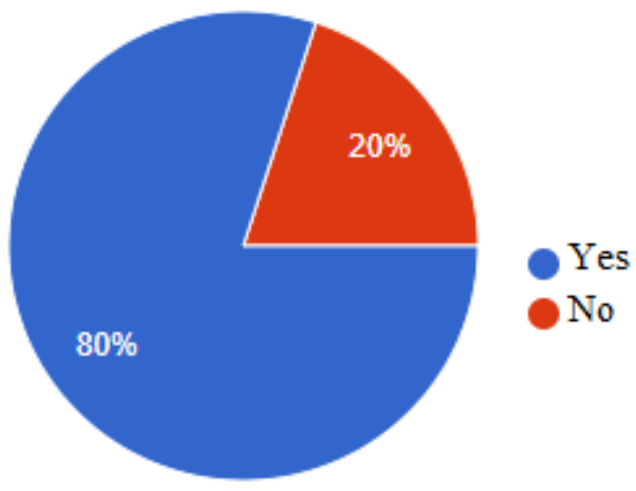

Fig.8 Number of Online Merchants

As for a small proportion who have not made online sales, the reason is that these traders $(77.8 \%)$ do not understand how to sell online, while others are satisfied with the present way of selling, some have not thought of selling online, and there are also due to unsupportive conditions such as not subscribing to the internet and so on with a percentage of $11.1 \%$.

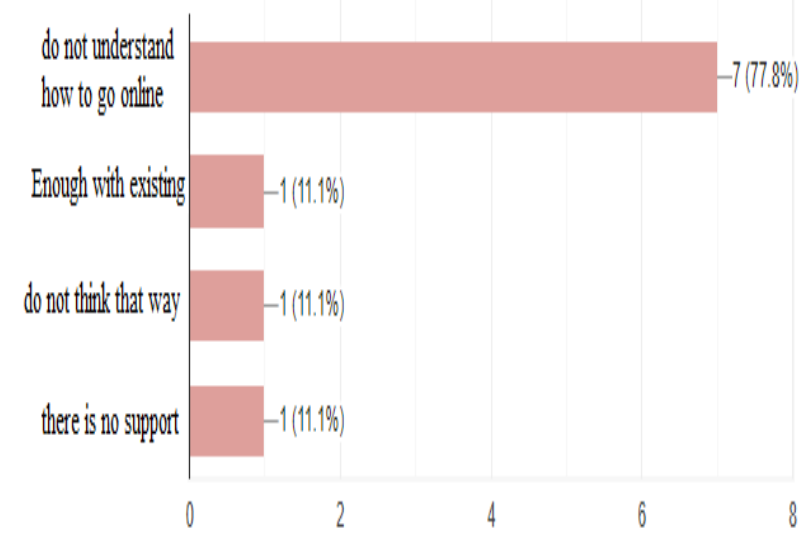

Fig.9 Reasons Not Online

These findings are consistent with other findings which explain that the community has not implemented digital marketing due to MSME actors' limited knowledge and then the technical constraints, such as the absence of e-commerce quality standards, system security, and reliability. Bandwidth, web server and network issues. Meanwhile, non-technical constraints are regulation, and the perception that e-commerce is unsafe and expensive. [5] 
Regarding the perception of insecurity on the internet, the element of trust is an important factor in the current era of computer-mediated communication. In e-commerce, the element of trust is an aspect that underlies the ongoing transaction process and needs to be managed properly because it can affect the adoption and development of the e-commerce sector. [6] In Kearney's research, it is known that the reasons consumers feel insecure in conducting e-commerce transactions are the existence of regulatory gaps, no cross-border jurisdiction', and the existence of cybercrime, which is difficult to avoid. [7]

\subsection{The Number of Merchants Needs Online Sales.}

Previous findings show that $80 \%$ of traders have marketed their products online, although they are also willing to sell them online by the Lathon application or marketplace. The number of participants who were willing to be assisted with their sales online was $98 \%$, while the remaining $2 \%$ answered doubts. As shown in the following picture:

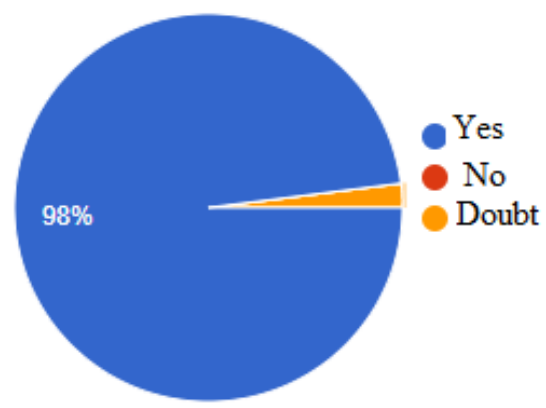

Fig.10 The Number of Merchants Needs Online Sales

This is understandable because based on other findings, it is known that most of the merchants who sell online market their products by social media $(86.1 \%)$ and instant messaging (61.1\%), while only a small proportion of those market selling by mobile applications $(8, \%)$ so that the majority who have not used the application or marketplace answer that they are willing if their product is marketed by the mobile application like the Lathon marketplace.

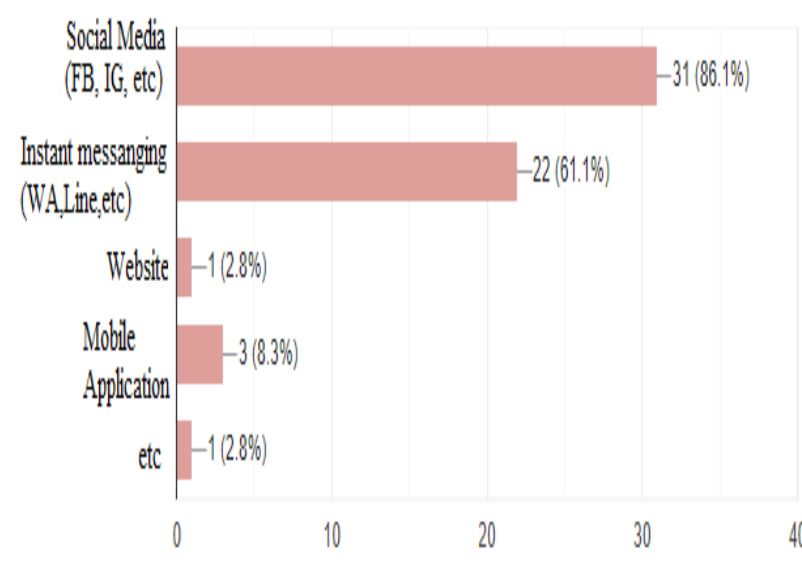

Fig.11 Online Sales Media

E-commerce activities that were originally website-based have shifted to mobile applications. This is due to the large number of mobile device users and also to make it easier for e-commerce users. E-commerce mobile applications make it easier for users to access e-commerce anytime and anywhere. [8]

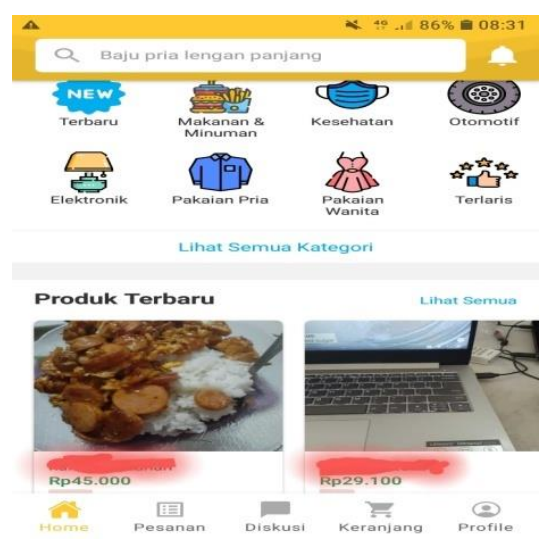

Fig.12 Mobile Application (Lathon Marketplace)

\section{CONCLUSION}

Based on the discussion above and the purpose of the research, we can conclude that 1)There is a decrease in daily income after the COVID-19 pandemic. Before COVID-19, 58\% of traders earned 50k-100k daily, but after COVID-19, the percentage of traders who had $50 \mathrm{k}-10 \mathrm{k}$ incomes decreased to $24 \%$. Initially, they earn $50 \mathrm{k}-100 \mathrm{k}$ to be less than 50k. Before COVID-19, $6 \%$ of traders earned $>500 \mathrm{k}$, but after COVID-19, it decreased to $2 \%$. The average daily income decreased by $50 \%$. 2) In the program, 50 traders were recorded, 
consisting of $24 \%$ Street Vendors and $76 \%$ SMEs affected by COVID-19. 3) The number of participants who were willing to be assisted by their sales online was $98 \%$, while the remaining $2 \%$ were in doubts.

The type of business most affected by COVID19 is a culinary, at about $74 \%$, which is a basic (physical) need that must be fulfilled because it is also a basic human right. . One of the solutions is by carrying out digital transformation for $20 \%$ of conventional traders by utilizing digital spaces to market products. Efforts are affected by COVID19 , especially culinary because it is a basic need of society and is a human right protected by laws and regulations.

\section{REFERENCES}

[1] H. Hamjen, "Persepsi Masyarakat Tentang Dampak Isi Ulang Pulsa Di ATM Terhadap UMKM Penjual Pulsa Seluler," Penelit. Pers dan Komun. Pembang., vol. 18, no. 1, pp. 31-44, 2014.

[2] D. Sugiri, "Menyelamatkan Usaha Mikro, Kecil dan Menengah dari Dampak Pandemi COVID-19," Fokus Bisnis Media Pengkaj. Manaj. dan Akunt., vol. 19, no. 1, pp. 7686, 2020, doi: 10.32639/fokusbisnis.v19i1.575.

[3] Z. Zamrudi and T. Wicaksono, "Promoting the Use of Social Commerce on SME in the Context of Logistics: UTAUT Model Examination," LOGI - Sci. J. Transp. Logist., vol. 9, no. 2, pp. 73-82, 2018, doi: 10.2478/logi-2018-0020.

[4] Z. Rifai and D. Meiliana, "PENDAMPINGAN DAN PENERAPAN STRATEGI DIGITAL MARKETING BAGI UMKM TERDAMPAK PANDEMI COVID-19," vol. 1, no. 4, pp. 604-609, 2020.

[5] A. Firmansyah, "Kajian Kendala Implementasi E-Commerce Di Indonesia," Masy. Telemat. Dan Inf. J. Penelit. Teknol. Inf. dan Komun., vol. 8, no. 2, p. 127, 2018, doi: 10.17933/mti.v8i2.107.

[6] L. Agustina, A. O. Fayardi, and I. Irwansyah, "Online Review: Indikator Penilaian Kredibilitas Online dalam Platform E-commerce," J. ILMU Komun., vol. 15, no. 2, p. 141, 2018, doi: 10.24002/jik.v15i2.1320.

[7] D. Paryadi, "Pengawasan E Commerce Dalam Undang-Undang Perdagangan Dan Undang-Undang Perlindungan Konsumen,"
J. Huk. Pembang., vol. 48, no. 3, p. 652, 2018, doi: 10.21143/jhp.vol48.no3.1750.

[8] E. Turban, D. King, J. K. Lee, T.-P. Liang, and D. C. Turban, Electronic Commerce - A Managerial and Social Perspective. 2015.

[9] U. Usaha, K. Dan, and E. Miranda, "Pemakaian E-commerce Untuk Usaha KEcil dan Menengah Guna Meningkatkan Daya Saing," Comtech, vol. 4, no. 2, pp. 638-645, 2013.

[10] B. T. Djata, "Pendekatan Hierarki Abraham Maslow Pada Prestsi Kerja Karyawan PT.Madubaru (PG Madukismo) Yogyakarta," Perilaku dan Strateg. Bisnis, vol. 6, no. 1, pp. 78-102, 2018, doi: 10.26486/jpsb.v6i1.

[11] I. Iskandar, "Implementasi Teori Hirarki Kebutuhan Abraham Maslow terhadap Peningkatan Kinerja Pustakawan," Khizanah Al-Hikmah, vol. 4, no. 1, pp. 2334, 2016, doi: 10.24252/kah.v4i1a2.

[12] N. Hikma, “Aspek psikologis tokoh utama dalam novel," Humanika, vol. 3, no. 15, 2015.

[13] H. Hamjen and B. Zaman, "COMPARISON OF E-COMMERCE CONSUMPTION TO INCOME," pp. 153166, 2020.

[14] A. Amri, "Dampak COVID-19 Terhadap UMKM di Indonesia," J. Brand, vol. 2, no. 1, pp. 147-153, 2020, [Online]. Available: https://www.academia.edu/42672824/Damp ak_COVID-

19_Terhadap_UMKM_di_Indonesia.

[15] W. laura Hardilawati, "Strategi Bertahan UMKM di Tengah Pandemi COVID-19," J. Akunt. dan Ekon., vol. 10, no. 1, pp. 89-98, 2020, doi: 10.37859/jae.v10i1.1934.

[16] C.- Implikasi and B. Usaha, "COVID-19 Dan Implikasi Bagi Usaha Mikro, Kecil, Dan Menengah," J. Ilm. Hub. Int., vol. 0, no. 0 , pp. 59-64, 2020, doi: 10.26593/jihi.v0i0.3870.59-64.

[17] R. Widi, "Uji Validitas Dan Reliabilitas Dalam Penelitian Epidemiologi Kedokteran Gigi," Stomatognatic, vol. 8, no. 1, pp. 2734, 2011. 